\title{
POVIJESNI RAZVOJ PRAVA NA SAMOODREĐENJE IZMEĐU DVA RATA - LENJIN VS. WILSON
}

Sažetak: Okončanje dvaju velikih svjetskih ratova i nestajanje dotadašnjih političkih režima rezultirali su stvaranjem novih država u međunarodnom poretku. Raspadom višenacionalnih država i buđenjem nacionalne svijesti počinju se javljati težnje naroda za vlastitim nacionalnim državama. Zahtjevi za samoodređenjem javljaju se prvenstveno kao rezultat dekolonizacijskog procesa, ali i kao odraz političkih odnosa u poslijeratnoj Europi. Po završetku Prvog svjetskog rata javljaju se događaji i ljudi koji će svojim stavovima nemalo pridonijeti razvoju prava naroda na samoodređenje, a konačno i potlačenim nacijama pomoći u ostvarenju težnji da same odlučuju o svojoj sudbini unutar vlastite nacionalne države. S jedne strane to je radničko samoodređenje i revolucija u Rusiji kao bitni elementi u razvoju prava na samoodređenje naroda u političko načelo i Lenjinovi stavovi o pitanju samoodređenja. S druge strane to je četrnaest točaka i američki predsjednik Woodrow Wilson sa svojim stavovima o pravu naroda na samoodređenje.

Ključne riječi: $\quad$ međunarodno pravo, samoodređenje naroda, pravo na samoodređenje, ruska revolucija, Četrnaest točaka Woodrowa Wilsona

\section{UVOD}

Čitav je niz povijesnih zbivanja koja su između dva velika rata dvadesetog stoljeća utjecala na razvoj prava na samoodređenje naroda, na stvaranje nove slike svijeta i posljedično novog međunarodnog poretka. Raspadom višenacionalnih država nakon Prvog svjetskog rata i buđenjem nacionalne svijesti, javljaju se težnje naroda za vlastitim nacionalnim državama. U ostvarenju težnji potlačenih nacija da same odlučuju o svojoj sudbini unutar vlastite nacional-

\footnotetext{
* Sanja Bježančević, mag. oec., doktorandica na Poslijediplomskom interdisciplinarnom sveučilišnom studiju Europski studiji, Sveučilište Josipa Jurja Strossmayera u Osijeku, Trg Svetog Trojstva 3, 31000 Osijek. E-adresa: sanja.bjezancevic@gmail.com. ORCID: https://orcid.org/0000-0002-5253-2581.
} 
ne države, odnosno u razvoju prava na samoodređenje pomogli su svojim stavovima američki predsjednik Wilson i ruski revolucionar Lenjin.

Kao bitni elementi nužni za razumijevanje specifičnosti ovog, prvo političkog, a potom načela međunarodnog prava, spominju se pojmovi nacije, suverenosti i nacionalizma. Radničko samoodređenje i revolucija u Rusiji bili su bitni elementi u razvoju prava na samoodređenje naroda u političko načelo, kao i Lenjinovi stavovi o pitanju samoodređenja. Usporedno $s$ Lenjinom, i američki predsjednik Woodrow Wilson jasno iznosi svoje stavove po pitanju prava na samoodređenje naroda. Cilj je ovoga rada prikazati ključne stavove dvojice političara koji su imali nemjerljiv utjecaj na razvoj prava na samoodređenje, a konačno i na međunarodni poredak po završetku Prvog svjetskog rata. Metodom komparacije prikazuju se osnovne razlike njihovih stavova o pitanju samoodređenja naroda. Može se pretpostaviti da su stavove dvojice političara oblikovali, među ostalim, i politički sustavi u kojima su živjeli.

\section{STVARANJE NACIJA}

Pravo na samoodređenje danas je opće priznato načelo međunarodnog prava, a moderno shvaćanje međunarodnog prava pravo na neovisnost priznaje i onim narodima koji još nisu stvorili vlastitu državu. U toj činjenici sadržano je pravo značenje prava na samoodređenje. ${ }^{1}$ Pravo naroda na samoodređenje proizašlo je iz prirodnog prava, odnosno iz ideje slobode zajamčene pojedincu, a potom i narodu kroz upravljanje vlastitom sudbinom. Kao ishodište ideje samoodređenja izdvaja se teorija o pravu naroda na vlastitu državu čiji je tvorac krakovski profesor Paweł Włodkowic, koja tek krajem 18. stoljeća prerasta u političko načelo koje potom postupno dobiva i svoj pravni okvir. ${ }^{2}$ Ipak, za razumijevanje problematike vezane uz pravo na samoodređenje, potrebno je krenuti od nastanka naroda i nacija, a potom i država i njihova pojmovnog pojašnjenja. ${ }^{3}$

\subsection{NAROD I NACIJA}

Za razliku od plemena (obitelji, bratstva) kao manje razvijenog oblika životne zajednice čije članove povezuje krvno srodstvo, narode i nacije kao razvijeniji oblik zajednice povezuju kultura, zajednički jezik, vjera ili druga nesrodna karakteristika. Nacija i nacionalni identitet moderni su fenomeni koji su se oblikovali u procesu transformacije tradicionalnog načina života koji započinje formiranjem etničke zajednice dominantnog naroda, a potom nacije-države koju čine dominantni narod i sve etničke skupine unutar zemlje. Na proces transformacije jednostavnih zajednica u narod i nacije, osim geografskih, djelovali su politički

$1 \quad$ Juraj Andrassy i drugi, Međunarodno pravo, vol 1 (Školska knjiga 2010) 113-14.

2 Edward Haliżak, 'Polish International Relations Studies and Post-Historiography, Disciplinary Development after the Cold War' (2016) 40 Revista UNISCI / UNISCI Journal 120-22. Vidi i: Ivo Škrabalo, Samoodređenje i odcjepljenje: pouke iz nastanka države Bangladeš (Školske novine 1997) 71. 
i kulturni utjecaji. ${ }^{4}$ Pojam nacije, dakle, podrazumijeva viši oblik organiziranja od naroda, odnosno društvenu skupinu koja se povijesno oblikovala, a čiji su međuljudski odnosi unutar skupine utemeljeni na kombinaciji kulturnih, jezičnih, vjerskih, političkih, geografskih i drugih elemenata. ${ }^{5}$ Osim kroz proučavanje spomenutih objektivnih elementa ili pokazatelja, istraživanju fenomena nacije pristupa se i kroz proučavanje subjektivnih elementa (kolektivne) svijesti koji kao nekritički elementi predstavljaju prepreku u iznalaženju univerzalne definicije ovog fenomena. ${ }^{6}$

Modernoj naciji i naciji-državi kao produktu građanskog društva prethodi narod, a takvu transformaciju zajednice na temelju etnosa prate razvoj obrazovanja, gospodarstva, tehnološki, kulturni i drugi razvoj. ${ }^{7}$ Kao prve moderne nacije ili nacije-države u literaturi izdvajaju se Francuska i Engleska, a izgradnja i rast dviju nacija podudaraju se s rastom nacionalne svijesti. ${ }^{8} \mathrm{Uz}$ razvoj nacionalne svijesti i nacionalnog identiteta, kao bitni elementi izgradnje nacija, navode se jezik i vjera kao elementi nacionalne kulture. Ideološki gledano, jezik i nacija su povezani, dok povijesno gledano govorimo o djelomičnoj povezanosti jezika i nacije koji se razvijaju paralelno. Uz jezik, značajan utjecaj na izgradnju nacija imala je i vjera, a nerijetko kao ključni element izgradnje nacionalne svijesti i nacionalnog identiteta ondje gdje je vladar države istovremeno bio i poglavar crkve. ${ }^{9}$

\subsection{PRAVO NA SUVERENOST}

U kontekst identiteta dovodi se i pravo naroda da se oslobodi ugnjetavanja od strane drugog naroda. Neizostavan je element identiteta, potaknut osjećajem straha i željom za opstankom, i element integracije, a ovdje pod identitetom mislimo na etnički identitet te pod integracijom na integraciju u neku zajednicu, narod ili naciju koju karakteriziraju zajednička obilježja poput jezika, vjeroispovijesti i kulture. ${ }^{10}$

4 Stjepan Ratković, 'Rasa, pleme, narod, nacija....' (1931) 3(1) Hrvatski geografski glasnik 206-08; Walker Connor, 'A nation is a nation, is a state, is an ethnic group is a...' (1978) 1(4) Ethnic and Racial Studies 378-81; Petar Korunić, Rasprava o izgradnji moderne hrvatske nacije: nacija i nacionalni identitet (Grafički zavod Hrvatske 2006) 12-18, 116-17; Vidi i: Petar Korunić, 'Nacija i nacionalni identitet' (2005) 36(1-2) Revija za sociologiju 87-88.

5 Hugh Seton-Watson, Nations and States: An Enquiry Into the Origins of Nations and the Politics of Nationalism (Routledge 2019) 7; Otto Bauer, 'Pojam nacije' (1983) 20(1) Politička misao 101; Vidi i: Miroslav Hroch, 'Oblikovanje modernih nacija i nacionalni pokret 19. stoljeća' (1979) 11(1) Časopis za suvremenu povijest 24.

6 Korunić, Rasprava o izgradnji moderne hrvatske nacije (n 4) 118-19. Davorka Matić, 'Nacionalizam, nacija i nacionalna država: Imaju li budućnost?' (2005) 14(1-2) Socijalna ekologija 78-79.

7 Korunić, Rasprava o izgradnji moderne hrvatske nacije (n 4) 119-20.

8 Seton-Watson (n 5) 21; Vidi detaljnije: Šefko Kurtović, Opća povijest prava i države, vol 2 (treće izdanje, Pravni fakultet 1994) 6-38, 145-250; Walker Connor, 'When is a nation?' (1990) 13(1) Ethnic and Racial Studies 92-93.

9 Budislav Vukas, Etničke manjine i međunarodni odnosi (Školska knjiga 1978) 18; Korunić, Rasprava o izgradnji moderne hrvatske nacije (n 4) 30; Alan Ford, 'Dependent or independent? The Church of Ireland and its colonial context, 1536-1649' (1995) 10(2) The Seventeenth Century 180; Stefan Berger, 'On the Role of Myths and History in the Construction of National Identity in Modern Europe' (2009) 39(3) European History Quarterly 496-497; Mira Lulić, 'Pravo na samoodređenje u suvremenom međunarodnom pravu' (Doktorska disertacija, Pravni fakultet Sveučilišta u Zagrebu 2005) 21-24; Ranko Bugarski, 'Jezik i nacija' (1984) 13(3) Književni jezik 108.

10 Avishai Margalit and Joseph Raz, 'National Self-determination' (1990) 87(9) Journal of Philosophy 442; Timothy Baumann, 'Defining ethnicity' (2004) 4(4) The SAA archaeological record 12; Vidi i: John Hutchinson and Anthony D Smith, Ethnicity 
Pravo na neovisnost ili suverenost jedno je od temelja međunarodnog prava, a pojam suverenosti javlja se s razvojem međunarodne zajednice, odnosno s razvojem europskih zemalja i očituje se jačanjem njihovih središnjih vlasti te promjenom odnosa prema ostalim državnim zajednicama u međunarodnom prostoru. ${ }^{11} \mathrm{U}$ društvenim znanostima pojam suverenosti shvaćen je isključivo kao moć koja pripada državama i koja se očituje kroz unutarnju političku vlast i vanjsku neovisnost. ${ }^{12}$ Koncept suverenosti povezan je dakle sa strukturom moderne države koja implicira neovisnost i formalnu jednakost s drugim državama u međunarodnoj zajednici. Ideja suverenosti, pak, prisutna je mnogo ranije u povijesti, od sinonima za vlasništvo do pravnopolitičkog pojma koji se razvijao paralelno s idejom države. Oblici državnog uređenja i značenje suverenosti mijenjali su se kroz vrijeme, a pojam suverenosti promatran kao apsolutni pojam, u praksi je pokazao ograničenja. Apsolutističke države 17. stoljeća duboko su se razlikovale od liberalnih država 19. i 20. stoljeća, a osim u oblikovanju međunarodne zajednice, načelo suverenosti važno je u samostalnosti odlučivanja naroda o vlastitoj sudbini. ${ }^{13}$

\section{NACIONALNO SAMOODREĐENJE}

Početak urušavanja feudalizma u Europi i razvoj građanskog društva značili su početak stvaranja modernih država čije oslobađanje od strane vlasti i uspostava vlastite predstavlja ključne elemente prava na samoodređenje koje u vremenu koje dolazi prerasta iz političkog načela u pravno. Samoodređenje se u 19. stoljeću počelo razvijati u pravo na nacionalno samoodređenje, a jačanje nacionalizma s jedne je strane riješilo mnoge tenzije, dok je s druge izazivalo nove. Nacionalizam je pomogao širenju kolonijalnih carstava, a s valom antikolonijalnih pokreta, konačno se i okrenuo protiv istih. Potreba za pronalaskom novih tržišta zbog straha od konkurencije, a potom i tehnološki i kulturni napredak, rezultirali su novim kolonijalnim težnjama tadašnjih kolonijalnih sila koje su prerasle obalne dijelove afričkog kontinenta. Ekonomska, a potom i vojna nadmoć, stvorila je poredak superiornih i inferiornih naroda. ${ }^{14}$

\subsection{RAZVOJ SAMOODREĐENJA U VREMENU PRIJE PRVOG SVJETSKOG RATA}

Osim sadržajno, prema prostoru na unutarnje i vanjsko te prema području na političko, kulturno te ekonomsko, samoodređenje je u znanstvenoj literaturi analizirano i kroz faze

(OUP 1996) 4-7; Lulić (n 9) 6; Margaret Moore, 'On National Self-Determination' (1997) 45(5) Political Studies 905-907; Ervin Maurič, 'Europski novi identitet' (1994) 3(6) Društvena istraživanja 696.

11 Andrassy (n 1) 112-13; Jean L Cohen, 'Whose Sovereignty? Empire Versus International Law' (2004) 18(3) Ethics \& International Affairs 5-11.

12 Kirby Brown, 'Sovereignty' (2018) 53(1) Western American Literature 81.

13 Jorge Emilio Núñez, 'About the Impossibility of Absolute State Sovereignty' (2014) 27(4) International Journal for the Semiotics of Law 653, 663; Tomas J Biersteker, 'State, sovereignty and territory' in W Carlsnaes, T Risse and BA Simmons (eds), Handbook of International Relations (2nd end, Sage 2002) 245-46; Luke Glanville, 'The Myth of “Traditional” Sovereignty' (2013) 57(1) International Studies Quarterly 80-81.

14 Lulić (n 9) 25-28, 107-108; Omar Dahbour, 'Self-determination in political philosophy and international law' (1993) 16(4-6) History of European Ideas 879. 
povijesnog razvoja. ${ }^{15} \mathrm{U}$ razmatranju povijesnog razvoja prava na samoodređenje, oslanjamo se na Vučinićevu podjelu prava na samoodređenje u četiri faze od kojih su nam za ovaj rad značajne prve dvije faze razvoja prava na samoodređenje koje obuhvaćaju razdoblje do završetka Prvog svjetskog rata. Prva, antifeudalna ili nacionalno-konstitutivna faza odnosi se na događaje u SAD-u i zapadnoj Europi krajem 18. i početkom 19. stoljeća, dok se antiimperijalna faza odnosi na događaje netom po završetku Prvog svjetskog rata i priznavanje prava na samoodređenje Versajskim mirovnim ugovorom. Treća i četvrta faza odnose se na vrijeme nakon Drugog svjetskog rata, antikolonijalna faza obuhvaća razdoblje od završetka Drugog svjetskog rata do kraja šezdesetih godina 20. stoljeća, a antikomunistička razdoblje od pada Berlinskog zida. ${ }^{16}$

Kao ključne događaje u razvoju prava na samoodređenje u vremenu prije Prvog svjetskog rata valja navesti francusku borbu protiv vlasti koja ugnjetava narod kojim vlada i američku borbu protiv kolonijalne (strane) vlasti. Američka borba protiv engleskih vlasti bila je prvenstveno ekonomska, kao odgovor na trgovinske namete po završetku Sedmogodišnjeg rata. Također, ona je bila i politička što je vidljivo iz jasne želje za jačom unutarnjom autonomijom. Rezultat te borbe Deklaracija je o neovisnosti iz 1776. godine kojom je trinaest američkih kolonija izborilo svoju neovisnost od britanske krune. ${ }^{17}$ Američka Deklaracija o neovisnosti poziva se na prirodno pravo, dok francuska Deklaracija o pravima čovjeka i građanina iz 1789. godine to pravo još naglašava i prenosi ga na odnose u međunarodnoj zajednici. Načelo samoodređenja naroda time nije isključivo samo pravo francuskog naroda, već svih naroda. ${ }^{18}$ Francuska revolucija, pozivanjem na jedinstvo temeljeno na zajedničkoj povijesti, velikim je dijelom zaslužna za stvaranje francuske nacije. Zbog velike etničke i vjerske heterogenosti, revolucija se pozivala na građanska prava i zajednički (nametnuti) francuski jezik, a dajući terminu nacija novo političko značenje, suprotstavila je građanstvo ili Treći stalež plemstvu. ${ }^{19}$

\subsection{NACIONALIZAM I PRAVO NA SAMOODREĐENJE}

Nacionalizam i pravo na samoodređenje nisu istoznačnice, ali veza između nacionalizma i nacionalnih pokreta i zahtjeva za samoodređenje jasno je vidljiva. Nacionalizam može, i često jest, ishodište zahtjeva za samoodređenjem, odnosno postao je najistaknutiji diskurzivni oblik modernih zahtjeva za političkom autonomijom i samoodređenjem. Nacionalizam i ono što danas zovemo modernom nacijom, razvili su se kroz procese u 18. i 19. stoljeću koji su potpuno

15 Antonio Cassese, Self-Determination of Peoples - A Legal Reappraisal (Cambridge University Press 1995) 96-102; Benyamin Neuberger, 'National self-determination: A theoretical discussion' (2001) 29(3) Nationalities Papers 392-93; Brad Simpson, 'The United States and the Curious History of Self-Determination' (2012) 36(4) Diplomatic History 682-83.

16 Nebojša Vučinić, 'Pravo naroda na samoopredeljenje' [2002] 3-4 Prava čoveka 13-20, prema: Slobodanka Bursać, 'Pravo na samoopredeljenje naroda' (2010) 62(2) Međunarodni problemi 287-391.

17 Declaration of Independence (July 4 1776) <https://avalon.law.yale.edu/18th_century/declare.asp> pristupljeno 27. ožujka 2021; Cassese (n 15) 11-13; Joshua Castellino, International law and self-determination: the interplay of the politics of territorial possession with formulations of post-colonial national identity (Martinus Nijhoff Publishers 2000) 11-13; Kurtović (n 8) 82-88; Lulić (n 9) 25-28, 107-08.

18 Declaration of the Rights of Man (National Assembly of France, August 26 1789) <https://avalon.law.yale.edu/18th_century/ rightsof.asp> pristupljeno 27. ožujka 2021; Dalibor Čepulo, 'Francuska revolucija i Deklaracija o pravima čovjeka i građanina 1789. godine: problemi političke demokracije’ (1989) 21(1-3) Časopis za suvremenu povijest 168-75; Škrabalo (n 2) 71-72.

19 Harris (n 3) 193; Zvonko Posavec, 'Nacija i nacionalizam kao temeljni fenomen političkoga' (1996) 33(2-3) Politička misao 226-27; Kurtović (n 8) 154-55. 
izmijenili izgled karte svijeta. ${ }^{20}$ Dotadašnji politički sustavi zahvaćeni pitanjem legitimnosti i nastanak novih država rezultirali su djelovanjem širih društvenih slojeva i naglasak stavili na naciju. Nacija postaje sudionik političkih zbivanja, a nacionalizam određeni politički autoritet koji legitimnom državom smatra samo onu državu koja proizlazi iz kolektivne volje neke nacije. Kako su pak rijetke one države koje su etnički homogene, izjednačavati naciju i državu je pogrešno. Snaga nacionalizma i nacionalnih pokreta ogleda su u nacionalnim mitovima, odnosno nacionalnoj povijesti, a njihova prepoznatljivost i povezanost $s$ vrijednostima zajednice kojoj se obraća, važna je za privlačenje i aktivaciju masa. Međutim, da bi nacionalni pokret bio uspješan, mora se obraćati već postojećoj zajednici bez obzira na to ima li ona jasnu svijest o vlastitoj osobnosti. ${ }^{21}$

Nastojanja nekih naroda da ostvare kolektivnu autonomiju utemeljenu na nepolitičkim razlozima, poput nastanjenosti nekog prostora ili nekog etničkog obilježja, također su iznjedrili neke slučajeve nacionalizma. Ipak, jasna razlika između etničkog oblika nacionalizma i onog političkog postoji. Cilj je političkog oblika nacionalizma ujediniti pripadnike neke zajednice pod zajedničkim političkim institucijama i on podrazumijeva odanost kolektivnom samoodređenju bez obzira na različita etnička obilježja. Politički nacionalizam pretpostavlja da oni koji nastanjuju određenu državu ili teže vlastitoj državi dijele osjećaj političkog identiteta što se pak može promatrati kao traženje suvereniteta. ${ }^{22}$

\section{POVIJESNI RAZVOJ PRAVA NA SAMOODREĐENJE IZMEĐU DVA RATA}

Idući važan trenutak u razvoju prava na samoodređenje jesu događaji vezani uz Prvi svjetski rat i međunarodni poredak koji je stvoren nakon rata. Pitanjem samoodređenja početkom prošlog stoljeća intenzivno se bavio Lenjin, a paralelno s Lenjinom i američki predsjednik Wilson. Oba državnika, promovirajući svoje teze i stavove vezane uz pravo na samoodređenje naroda, promovirali su vlastito viđenje novog svjetskog poretka po završetku Prvog svjetskog rata. Komparacija stavova jasno pokazuje prvog kao zagovaratelja radničkog samoodređenja i širenja komunističkih vrijednosti, a drugoga kao zagovaratelja samoodređenja mirnim putem i demokratskih vrijednosti. Iako ni jedan ni drugi pitanje samoodređenja nisu u potpunosti razjasnili, dali su značajan doprinos u razvoju prava na samoodređenje koje se od političkog načela razvilo u načelo međunarodnog prava. ${ }^{23}$

\footnotetext{
20 Lulić (n 9) 33; Ben Jackson, 'The Political Thought of Scottish Nationalism' (2014) 85(1) The Political Quarterly 51-55; Craig Calhoun, 'Nationalism and Ethnicity' (1993) 19(1) Annual Review of Sociology 212-14; Anthony D Smith, 'Nationalism and Classical Social Theory' (1983) 34(1) The British Journal of Sociology 22-23.

21 Matić (n 6) 80; Lulić (n 9) 36.

22 Stanford Lakoff, 'Nacionalizam i demokracija' (2000) 37(1) Politička misao 57-58; Anthony D Smith, 'The ethnic sources of nationalism' (1993) 35(1) Survival 58-61. 


\subsection{RADNIČKO SAMOODREĐENJE I RUSKA REVOLUCIJA}

Rusko Carstvo razvijalo se kao multinacionalna država, a jedini povezujući element u začetku bila je dinastija Romanov na čelu Carstva. Postojeća autonomija postupno je nestajala i Rusko se Carstvo počelo razvijati u centraliziranu državu. S rastućim unitarizmom i centralizmom, nakon revolucije 1905. godine, počinje se u političkim raspravama javljati i pitanje nacionalne problematike. Stranke koje su tada zagovarale rušenje postojećeg političkog, ali i društveno-ekonomskog modela takve državne konstrukcije, pripadale su socijalističkoj grupaciji i krajnji cilj im je bio uspostava socijalističkog društvenog uređenja. Socijalističkoj grupaciji pripadale su Socijalistička revolucionarna stranka, koja je nastala iz narodnjačke tradicije i Socijaldemokratska radnička stranka Rusije koja je zagovarala "marksističku ideološku matricu o društvenom napretku kroz smjenu društveno-ekonomskih formacija i borbu antagonističkih klasa”. ${ }^{24}$ Spajanjem lokalnih socijaldemokratskih stranaka u jednu, na Prvom stranačkom kongresu u Minsku, utemeljena je 1898. godine Socijaldemokratska radnička stranka Rusije. ${ }^{25}$ Ujedinjavanje je bilo otežano jer su nakon spomenutog kongresa vodeći ljudi stranke uhićeni, a rad onemogućen. U inozemstvu su tako pokrenute novine koje su tajno dopremane u Rusiju, a jednu od glavnih riječi u novinama imao je Vladimir Iljič Lenjin. Na Drugom kongresu održanom 1903. godine izabrano je stranačko vodstvo i usvojen je program stranke podijeljen u dva dijela. Prvi dio programa "sadržavao je ciljeve koje bi trebala ispuniti građansko-demokratska revolucija”, poput uvođenja tajnog glasovanja i ostvarenje prava na samoodređenje svih neruskih nacija, dok je drugi dio programa predviđao preustroj društvenog uređenja na socijalističkim načelima i uspostavu diktature proletarijata. ${ }^{26}$

O nacionalnom pitanju Lenjin piše još 1903. godine u članku pod nazivom Nacionalno pitanje u našem programu u časopisu Iskra gdje navodi bezrezervno priznavanje borbe za samoodređenje, ali ne i obvezu podupiranja svakog zahtjeva za samoodređenje. Lenjin navodi kako će se socijaldemokrati suprotstavljati svakom nasilju usmjerenom prema zahtjevu za samoodređenje te kao svoj najvažniji zadatak uzimaju ipak promicanje samoodređenja proletarijata unutar narodnosti ispred samoodređenja naroda. ${ }^{27}$ Lenjin se pitanjem samoodređenja aktivno bavio u periodu od 1914. do 1916. godine, kada u članku pod nazivnom Socijalistička revolucija i pravo naroda na samoodređenje navodi kako socijalizam mora uspostaviti punu demokraciju, a shodno tomu ne samo punu jednakost nacija nego i pravo potlačenih nacija na samoodređenje, odnosno pravo na slobodno političko razdvajanje. Nadalje, socijalističke stranke koje ne pokažu spremnost osloboditi porobljene narode i izgraditi odnos s njima na temelju slobodnog saveza koji bi bez prava na odcjepljenje bio obična fraza, izdale bi prema Lenjinu socijalizam. ${ }^{28}$

Ruska revolucija dala je bitan poticaj oblikovanju prava na samoodređenje u opće političko načelo kao i promjene u međunarodnom poretku koje su uslijedile po završetku Prvog svjetskog

Joško Pavković, Ruska dualistička monarhija (Društvo za socijalnu podršku 2012) 40.

Edward Hallett Carr, Ruska revolucija, Od Lenjina do Staljina 1917.-1929. (Globus 1984) 21-22; Richard Mullin, The Russian Social-Democratic Labour Party, 1899-1904: Documents of the 'Economist' Opposition to Iskra and Early Menshevism (Brill 2015) 1-2.

Pavković (n 24) 40-43.

Vladimir I Lenin, Lenin Collected Works, vol 6 (Progress Publisher 1964) 452.

Vladimir I Lenin, Lenin Collected Works, vol 22 (Progress Publisher 1964) 143; Lulić (n 9) 41. 
rata. ${ }^{29}$ Lenjin, čije su zasluge u tome što je brojnim polemikama unutar radničkog pokreta pravo na samoodređenje "postupno raščistio u tom smislu da ono znači pravo na odcjepljenje", ${ }^{0}$ ipak nije dao odgovor na pitanje koja se zajednica može smatrati nacijom. Problem na koji načelo samoodređenja nailazi jest dakle pitanje volje nacije, odnosno definiranje zajednica koja se smatra nacijom. ${ }^{31}$ Poznatu polemiku o samoodređenju nacija Lenjin je vodio s Rosom Luxemburg koja je nacionalnu državu vidjela kao apstrakciju što je u suprotnosti s Lenjinovim stavom da je stvaranje nacionalnih država najbolji odgovor modernom kapitalizmu. Gledano s povijesno-ekonomskog aspekta, Lenjin navodi da samoodređenje ne može značiti ništa drugo nego stvaranje nacionalne države. ${ }^{32}$ Iako je Lenjin isticao univerzalnost prava na samoodređenje, to pravo ipak nije bilo neograničeno. Naime, njegovo viđenje samoodređenja bilo je podređeno volji proletarijata, odnosno za proletarijat je važno "osigurati razvitak svoje klase" pa tako proletarijat "priznajući jednako pravo na nacionalnu državu, iznad svega stavlja savez proletera svih nacija", a svaki zahtjev za odcjepljenjem promatra kroz "klasne borbe radnika”. ${ }^{33} \mathrm{Za}$ Lenjina, ali i Staljina, kulturno-nacionalna autonomija nije zadovoljavajuća, a Staljin kao ključni element u rješavanju nacionalnog pitanja navodi regionalnu autonomiju. Za Staljina pravo na samoodređenje znači pravo na odcjepljenje i uređivanje vlastita života na način na koji sam narod to želi. ${ }^{34}$

Revolucija u Rusiji započela je u ožujku 1917. godine rušenjem autokratske vlasti, a nakon donošenja zakona o amnestiji političkih disidenata, Lenjin se vraća u Rusiju i u časopisu Pravda objavljuje svoje Travanjske teze u kojima se suprotstavlja nastavku ruskog sudjelovanja u imperijalističkom ratu koji proizlazi iz kapitalističke prirode privremene vlade te zagovara prelazak u drugu fazu revolucije koja podrazumijeva prijenos vlasti u ruke proletarijata i najsiromašnijih slojeva seljaka, reorganizaciju partije uz promjenu imena te obnovu Internacionale. U jesen 1917. boljševici preuzimaju vlast, a kako bi riješila nacionalističke zahtjeve koji se počinju javljati, nova vlast donosi Deklaraciju o pravima naroda Rusije kojom jamči narodima pravo na samoodređenje do odcjepljenja i stvaranje vlastite nacionalne države. Dekretom o miru iz iste godine, naglašena su načela samoodređenja naroda do odcjepljenja što je boljševicima privuklo narode s područja bivšeg Carstva, a dekret je upućen svim zaraćenim narodima. Lenjin tako pravo na samoodređenje primjenjuje na sve narode. ${ }^{35}$ Deklaracijom o pravima radnog i eksploatiranog naroda iz 1918. postaje jasno da se Lenjin zbog bujanja nacionalnih pokreta nakon revolucije okreće federalizmu, privatno vlasništvo se ukida, crkva se odvaja od države, a kaos građanskog rata koji bijesni, "nije dopuštao nikakva određenja o teritoriju republike”. Deklaracija je postala dijelom Ustava Ruske Sovjetske Federativne

29 Lenin, Lenin Collected Works, vol 22 (n 28) 73.

30 Škrabalo (n 2) 73.

31 Lulić (n 9) 40-43.

32 Vladimir I Lenjin, O pravu nacija na samoodređenje (Kultura 1949) 5-10.

33 Ibid 20-21.

34 Vladimir I Lenin, Lenin Collected Works, vol 19 (Progress Publisher 1964) 504; Joseph V Stalin, Works, vol 2 (Foreign Languages Publishing House 1953) 321-75.

35 Lenjinove Travanjske teze detaljnije vidi u: Vladimir I Lenin, Lenin Collected Works, vol 24 (Progress Publisher 1964) 19-26; Vidi: Declaration of the Rights of the People of Russia (english translation from The Nation, December 28 1919) <https://www. marxists.org/history/ussr/government/1917/11/02.htm> pristupljeno 26. ožujka 2021.; Vladimir I Lenin, Report on Peace (Second All-Russia Congress of Soviets of Workers' and Soldiers' Deputies, October 26 (November 8)) <https://www.marxists. org/archive/lenin/works/1917/oct/25-26/26b.htm> pristupljeno 26. ožujka 2021; Hallett Carr (n 25) 22-27; Lulić (n 9) 45-46. 
Socijalističke Republike (RSFSR) u srpnju iste godine kojom polako kreće proces "priključenja autonomnih pokrajina RSFSR u kojima je živjelo većinom nerusko stanovništvo”. Najvažnije odluke vezane uz ekonomiju i vanjsku politiku donosile su se u Moskvi, a o stvaranju federalnih jedinica i stupnju samouprave koji će istima biti dodijeljen, odlučivali su ministarstvo o unutarnjim poslovima i ministarstvo o nacionalnostima na čijem je čelu bio Staljin. Boljševici su tako nastavili s politikom Ruskog Carstva, a završetkom građanskog rata i udruživanjem u SSSR, situacija se još radikalizirala. Na Dvanaestom kongresu tada već Komunističke partije SSSR-a održanom 1922. godine, Staljin je pravo sovjetskih država na samoodređenje do odcjepljenja pokušao potpuno ukinuti kako ne bi ugrozio novonastalu državu. Njegova namjera bila je "socijalističke republike imenovati autonomnim jedinicama federacije" što je Lenjin ipak uspio spriječiti. Staljinova politika rusifikacije, uokvirena u "borbu protiv buržoaskog nacionalizma", nastavljena je, a broj autonomnih jedinica do donošenja Ustava iz 1939., a i nakon njegova donošenja, povećan je. ${ }^{36}$

Lenjinovo pravo na samoodređenje imalo je tri bitne komponente. Zahtjev za samoodređenje može podnijeti ona nacionalna skupina koja o vlastitoj sudbini želi samostalno odlučivati. Potom, pravo na samoodređenje primjenjuje se vezano uz raspodjelu teritorija po završetku oružanog sukoba u situaciji kada se ne može ići protiv volje naroda koga se tiče pitanje raspodjele i konačno, samoodređenje ima antikolonijalnu dimenziju odnosno, ono će osigurati slobodu i neovisnost kolonijalnim područjima. ${ }^{37}$

\section{2. ČETRNAEST TOČAKA WOODROWA WILSONA}

Američki predsjednik Tomas Woodrow Wilson svoje viđenje prava na samoodređenje naroda promovirao je u isto vrijeme kada to čini Lenjin. Dok prema Lenjinu pravo na samoodređenje pripada jednako svim narodima, kako onima unutar Carske Rusije tako i narodima u drugim dijelovima svijeta, američki predsjednik Wilson ograničava pravo na samoodređenje na određene nacije. Lenjin je svoju koncepciju temeljio na socijalističkoj političkoj filozofiji, dok je Wilson svoju koncepciju temeljio na zapadnoj demokratskoj teoriji. Osim političke pozadine i međunarodne razine, Lenjinov i Wilsonov pogled razlikovao se i u tome što je prema Wilsonu u uređenju kolonijalnih zahtjeva u obzir trebalo uzeti i zahtjeve vlasti, ne samo zahtjeve kolonijalnog naroda. Ipak, američki predsjednik Wilson načelo samoodređenja učinio je središnjim pitanjem američke vanjske politike po ulasku njegove zemlje u Prvi svjetski rat. ${ }^{38}$

36 Tekst Deklaracije o pravima radnog i eksploatiranog naroda vidi u: Vladimir I Lenin, Lenin Collected Works, vol 26 (Progress Publisher 1972) 423-25; Constitution of the Russian Soviet Federated Socialist Republic (Adopted by the Fifth All-Russian Congress of Soviets, July 10 1918) <https://www.marxists.org/history/ussr/government/constitution/1918/index.htm> pristupljeno 26. ožujka 2021.; Hallett Carr (n 25) 28-38, 51-53; Kurtović (n 8) 285-330; Andrej Kotljarchuk, 'Ethnic cleansings and Russification' in Mats-Olov Olsson (ed), Encyclopedia of the Barents Region, vol 1 (Pax Forlag 2016) 189; Vidi i: Lulić (n 9) 47-48. 
Brojni su autori koji proglašenje prava na samoodređenje kao načela međunarodne politike vezuje upravo uz američkog predsjednika Wilsona i njegovih glasovitih Četrnaest točaka. ${ }^{39}$ Wilson je smatrao kako svijetu treba prezentirati američka stajališta i izložiti koncept za koji je vjerovao da može imati širu podršku pa je 8. siječnja 1918. u obraćanju američkom Kongresu objavio svoj program svjetskog mira poznat kao Četrnaest točaka. Bio je to program vanjske politike podijeljen $u$ četrnaest točaka, a odnosio se, među ostalim, i na uzimanje u obzir želja stanovništva pod kolonijalnom vlašću u postupku rješavanje kolonijalnog pitanja uz uvjet da te želje nisu oprečne kolonijalnim silama, ispravak talijanskih granica prema principu samoodređenja naroda, mogućnost samostalnog razvoja za narode Austro-Ugarske, ${ }^{40}$ neovisnost Turske i Poljske, samostalnost neturskih naroda unutar Osmanskog Carstva te osnivanje međunarodne organizacije $s$ ciljem osiguranja poštovanja prava naroda. ${ }^{41}$ Iako je zagovarao samoodređenje, Wilson ga, bojeći se posljedica koje bi ono izazvalo u Europi, izrijekom ne spominje i naglasak stavlja na "ideju poštivanja prava nacionalnosti." ${ }^{2}$ Wilsonovih Četrnaest točaka bile su odgovor na Lenjinov dekret o miru iz 1917., a osnovna razlika između stavova dvaju državnika bilo je pitanje kolonijalnih sila. Dok Lenjin govori o bezuvjetnoj samostalnosti kolonijalnih naroda, Wilson ih ipak ograničava interesima kolonijalnih sila. ${ }^{43}$

Prvi svjetski rat završen je s velikim brojem žrtava i propašću velikih carstava koja su predstavljala "srce otpora starih europskih režima”, a iza sebe je ostavio nered i veliku želju za kažnjavanjem poraženih sila. ${ }^{44}$ Po završetku rata, lideri pobjedničkih, ali i neutralnih sila u ratu, sastali su se 18. siječnja 1919. na mirovnoj konferenciji u Parizu, a na površinu mirovnih pregovora isplivale su nesuglasice oko podjele plijena. Francuska je i dalje imala problem s Njemačkom i odštetom je htjela Njemačku dodatno oslabjeti. Velika Britanija nije željela jačanje Njemačke i Francuske. Italija se brinula o obećanom teritoriju za ulazak u rat protiv Njemačke, dok se američki predsjednik Wilson zalagao za uspostavljanje trajnog mira i organizacije kojoj će trajni kolektivni mir biti osnovni cilj, zabranu tajnog djelovanja diplomacije te uspostavu samoodređenja naroda. Načela su to sadržana u Wilsonovih Četrnaest točaka. ${ }^{45}$

Načelo o samoodređenju nakon Prvog svjetskog rata manje se primjenjivalo izravnom primjenom samoodređenja, a više primjenom volje naroda ili pak na temelju viših interesa

39 President Woodrow Wilson's Fourteen Points (January 8 1918) <https://avalon.law.yale.edu/20th_century/ wilson14.asp> pristupljeno 27. ožujka 2021.; Škrabalo (n 2) 74-75; Trygve Throntveit, "The Fable of the Fourteen Points: Woodrow Wilson and National Self-Determination' (2011) 35(3) Diplomatic History 445-81.

40 Težnje o ujedinjenju svih zemalja u kojima žive Hrvati, Srbi i Slovenci u okviru Austro-Ugarske Monarhije u neovisno državno tijelo iznesene su 30. svibnja 1917. godine u Bečkom parlamentu. U deklaraciji poznatoj kao Svibanjska deklaracija, koju potpisuje 33 zastupnika Jugoslavenskog kluba u Bečkom parlamentu, težnje za ujedinjenjem polaze od narodnog načela i hrvatskog povijesnog državnog prava. O Svibanjskoj deklaraciji vidi detaljnije: Ferdo Šišić, 'Kralj Aleksandar I. Karađorđević (1888.-1934.)' (1934) 13(34) Narodna starina 121; Miro Kovač, 'Raspadanje Austro-Ugarske i rađanje Kraljevine SHS u svjetlu francuske politike (od listopada do prosinca 1918.)' (2003) 35(1) Časopis za suvremenu povijest 143; Ibrahim Karabegović, 'Kraljevina Srba, Hrvata i Slovenaca - Historijska realnost' (2009) 3 Historijska traganja 13; Vidi i: Igor Ivašković, 'Polemike o statusu Države i Kraljevine SHS' (2020) 36(3-4) Pravni vjesnik 270, 280-84.

41 Livia Kardum, Suton stare Europe - Europska diplomacija i Prvi svjetski rat, (Golden marketing -Tehnička knjiga 2009) 200-01; Cassese (n 15) 20; Goran Hutinec (ed), Prvi svjetski rat i poslijeratna Europa (1914.-1936.) (Jutarnji list 2008) 92.

42 Kardum (n 41) 249.

43 Lulić (n 9) 55.

44 Krešimir Regan (ed), Kolonijalna carstva i imperijalizam (1871.-1914.) (Jutarnji list 2008) 48.

45 Anthony Whelan, 'Wilsonian self-determination and the Versailles settlement' (1994) 43(1) International \& Comparative Law Quarterly 101-03; Davorin Rudolf, 'Lekcije Prvog svjetskog rata' (2014) 20 Adrias 108. 
velikih sila. ${ }^{46} \mathrm{Na}$ Mirovnoj konferenciji u Parizu Wilson je ulogu SAD-a vidio isključivo kao posredničku, a njegovi stavovi po pitanju prava naroda na samoodređenje, dominirali su. Etnička heterogenost u dijelovima Europe dodatno je otežavala pitanje prava na samoodređenje, odnosno ovlaštenika tog prava. Konačno, Versajski mirovni ugovor iz 1919. godine koji je proklamirao pravo na samoodređenje, funkcionirao je tako da poražene države u Prvom svjetskom ratu nisu imale pravo na samoodređenje. ${ }^{47}$ Samoodređenje i pokušaji stvaranja novih državnih granica nakon Prvog svjetskog rata doveli su do novih napetosti što je dijelom proizašlo iz činjenice da se pravo na samoodređenje stjecalo političkim, a ne pravnim mehanizmima. U većini slučajeva nije se vodilo računa o željama stanovništva što je rezultiralo rastom nacionalističkih osjećaja i pokreta, a konačno i novim svjetskim ratom. Zanimljivo je usporediti i dvije izjave američkog predsjednika Wilsona, jednu s početka rata o tome da svaka nagodba po pitanju teritorija mora biti sklopljena u interesu naroda kojega se tiče, a ne kao kompromis zahtjeva zaraćenih strana i jednu nakon rata da mirovna konferencija ipak nije bila ovlaštena djelovati po pitanju samoodređenja naroda, osim onih na teritorijima poraženih carstava. Značaj Versajskog mirovnog ugovora bio je važan utoliko što je rezultirao osnutkom Lige naroda i namjerom očuvanja svjetskog mira što su u konačnici države i prihvatile. U prvi nacrt Pakta Lige naroda uneseno je pravo na samoodređenje koje je, zbog izmjena koje su uslijedile, konačno ipak isključeno. Iako je Liga naroda uspješno razriješila neke sporove, njezin ključni cilj nije postignut, Liga naroda nije uspjela u očuvanju svjetskog mira. Završetkom rata, primjena samoodređenja naišla je na mnoge probleme. Njemačka je ostala bez svojih kolonija, a sile pobjednice rata smatrale su da njemačka kolonijalna područja nemaju dovoljno zrelosti za samostalno upravljanje. Odlučeno je da se ista stavljaju pod upravu sila pobjednica, ali uz nadzor Lige naroda što je rezultiralo pokazivanjem brige kolonijalnih sila o njihovim kolonijalnim područjima te posljedično dogovorom oko uspostave mandata. ${ }^{48}$ Iako rat nije donio značajnu promjenu u samom sustavu, zbog prisutne spoznaje o nepravdi kolonijalnih sila spram svojih kolonijalnih područja, iste nisu između sebe podijelile kolonijalna područja pobijeđenih sila na dotad uobičajen način. Tako su neke zemlje bivšeg Otomanskog Carstva i njemačke kolonije podijeljene u tri kategorije, prema stupnju njihova razvoja, dok su države koje su preuzele mandat svoje ovlasti provodile kao mandatar Lige naroda. Mandatar je morao Ligi naroda, odnosno Stalnom odboru za mandate, slati godišnje izvještaje, dok je vrhovni nadzor provodilo Vijeće Lige naroda. ${ }^{49}$

Njemačko nezadovoljstvo Versajskim mirovnim ugovorom i posljedicama gubitka rata rezultiralo je jačanjem nacionalizma i Hitlerovom zloupotrebom prava na samoodređenje prema kojemu bi svi Nijemci trebali biti ujedinjeni u jednu državu. Time je ideja samoodređenja postala sredstvo Hitlerove politike za dominacijom. Kao odgovor Hitlerovim namjerama uslijedila je početkom Drugog svjetskog rata zajednička izjava američkog predsjednika Roosevelta i britanskog premijera Churchilla poznata pod nazivom Atlantska povelja koja se poziva na načelo slobodnog izbora vlasti u svakoj državi. Polazišta Atlantske povelje o načelu samoodređenja kasnije su postala dio Povelje Ujedinjenih naroda. Deklaracijom s Jalte iz ožujka

\footnotetext{
46 Škrabalo (n 2) 73.

47 Margaret Macmillan, Paris 1919: Six Months That Changed the World (Random House 2002) 55-64: Alan Sharp, The Versailles settlement: peacemaking in Paris, 1919. (Macmillan 1991) 19-42.

48 Cassese (n 15) 20-27; Lulić (n 9) 67-80. 
1945. godine potvrđena su načela Atlantske povelje i naglašeno pravo svih naroda da ponovno ostvare svoju samoupravu koja im je oružanim agresijama u ratnim godinama oduzeta. Tri predsjednika potpisnika Deklaracije - Staljin, Roosevelt i Churchill - uzimajući u obzir njihove državne interese, razilazili su se oko shvaćanja načela samoodređenja. Staljin s pretenzijama na istočnoeuropske i balkanske zemlje, Roosevelt sa stavom da se samoodređenje treba odnositi na sve narode i Churchill protiv uvođenja novog instituta za kolonijalna područja, ipak su zauzeli stav da će nacistički i fašistički režimi biti uništeni, a osnutkom međunarodne organizacije oslobođenim će se narodima pomoći u uspostavi svjetskog mira. Okončanjem Drugog svjetskog rata utemeljena je Organizacija Ujedinjenih naroda, a o sudbini poraženih zemalja opet su odlučivale velike sile. Unatoč nekim protivljenjima, odredbe o samoodređenju postale su dio Povelje Ujedinjenih naroda, temeljnog dokumenta te organizacije. Time je samoodređenja postalo dio međunarodnog prava te je potom priznato i kao temeljno ljudsko pravo. ${ }^{50}$

\section{ZAKLJUČAK}

Uzimajući u obzir promjene u međunarodnoj zajednici od trenutka nastanka ideje o samoodređenju do danas, velike svjetske ratove, nestanke velikih carstava i nastanke novih država na njihovim granicama, pravo na samoodređenje ostaje kontroverzno i nedorečeno načelo koje ostavlja brojna otvorena pitanja. Pravo na samoodređenje, i sto godina nakon stvaranja novog svjetskog poretka, puno je paradoksa, a svaki postojeći zahtjev za samoodređenjem karakteriziraju specifične okolnosti. Na putu razvoja prava na samoodređenje do opće priznatog načela međunarodnog prava značajan doprinos pripisuje se Vladimiru Iljiču Lenjinu koji je samoodređenje uzvisio do političkog načela te Woodrowu Wilsonu koji je svojim idealiziranim stavovima o svjetskom miru načelo samoodređenja uvrstio u mirovni ugovor kojim je okončan Prvi svjetski rat.

Očite razlike u shvaćanju pojma naroda za koji ni danas ne postoji univerzalna definicija te konačno i razlike u shvaćanju koncepta samoodređenja koje za Lenjina, nipošto bezuvjetno, uključuje pravo na odcjepljenje, jasno pokazuju da su stavovi dvojice državnika o samoodređenju naroda oblikovani pod utjecajem političkih sustava u kojima su živjeli. Jednako značajno jest i to da su svoja viđenja samoodređenja Lenjin i Wilson podredili svojim političkim težnjama i slici novog svjetskog poretka koji se stvarao. Lenjin je ostvarenje samoodređenja promatrao kroz radničke revolucije u zemljama svijeta i širenje komunizma, dok je Wilson zagovarao ostvarenje samoodređenja mirnim putem i uspostavom demokratskih vlasti. Odnosno svoje viđenje samoodređenja naroda, u vidu novog svjetskog poretka, Lenjin je podredio komunističkoj Internacionali, a Wilson Ligi naroda. I primjena načela samoodređenja u vremenima koja su uslijedila nije bila lišena političkih utjecaja i interesa. Najbolji prilog u korist tvrdnji primjena je načela samoodređenja nakon završetka Prvog svjetskog rata koja je isključivi odraz političke volje tadašnjih ratnih pobjednika ili pak politika rusifikacije kao

50 Lulić (n 9) 96-105, 222; Cassese (n 15) 48-51; Povelja Ujedinjenih naroda (NN-MU 15/1993); United Nations General Assembly, Inclusion in the International Covenant or Covenants on Human Rights of an Article Relating to the Right of Peoples to Self-Determination (A/RES/545 (VI), 5 February 1952); Nicolaas Schrijver, 'Self-determination of peoples and sovereignty over natural wealth and resources' in Stephen Marks (ed), Realizing the Right to Development: Essays in Commemoration of 25 Years of the United Nations Declaration on the Right to Development (United Nations 2013) 97. 
odgovor na nacionalne pokrete koji se javljaju na području SSSR-a u vremenu nakon rata. Unatoč razlikama u njihovim stavovima, i Lenjinov i Wilsonov doprinos razvoju načela samoodređenja neupitan je, a kao otvoreno pitanje do danas ostaje politička pozadina kao konačni sud o opravdanosti svakog postojećeg zahtjeva za samoodređenje.

\section{BIBLIOGRAFIJA}

1. Andrassy J i drugi, Međunarodno pravo, vol 1 (Školska knjiga 2010)

2. Bauer O, 'Pojam nacije' (1983) 20(1) Politička misao 99

3. Baumann T, 'Defining ethnicity' (2004) 4(4) The SAA archaeological record 12

4. Berger S, 'On the Role of Myths and History in the Construction of National Identity in Modern Europe' (2009) 39(3) European History Quarterly 490

5. Biersteker TJ, 'State, Sovereignty and Territory' in Carlsnaes W, Risse T and Simmons BA (eds), Handbook of International Relations (2nd end, Sage 2002) 245-72

6. Brown K, 'Sovereignty' (2018) 53(1) Western American Literature 81

7. Bugarski R, 'Jezik i nacija' (1984) 13(3) Književni jezik 107

8. Bursać S, 'Pravo na samoopredeljenje naroda' (2010) 62(2) Međunarodni problemi 276

9. Calhoun C, 'Nationalism and Ethnicity' (1993) 19(1) Annual Review of Sociology 211

10. Cassese A, Self-Determination of Peoples: A Legal Reappraisal (Cambridge University Press 1995)

11. Castellino J, International Law and Self-determination: The Interplay of the Politics of Territorial Possession with Formulations of Post-colonial National Identity (Martinus Nijhoff Publishers 2000)

12. Cohen JL, 'Whose Sovereignty? Empire Versus International Law' (2004) 18(3) Ethics \& International Affairs 1

13. Connor W, 'A nation is a nation, is a state, is an ethnic group is a...' (1978) 1(4) Ethnic and Racial Studies 377

14. Connor W, 'When is a nation?' (1990) 13(1) Ethnic and Racial Studies 92

15. Čepulo D, 'Francuska revolucija i Deklaracija o pravima čovjeka i građanina 1789. godine: problemi političke demokracije' (1989) 21(1-3) Časopis za suvremenu povijest 161

16. Dahbour O, 'Self-determination in Political Philosophy and International Law' (1993) 16(4-6) History of European Ideas 879

17. Ford A, 'Dependent or Independent? The Church of Ireland and its Colonial Context, 1536-1649' (1995) 10(2) The Seventeenth Century 163

18. Glanville L, “The Myth of “Traditional” Sovereignty' (2013) 57(1) International Studies Quarterly 79

19. Haliżak E, 'Polish International Relations Studies and Post-Historiography, Disciplinary Development after the Cold War' (2016) 40 Revista UNISCI / UNISCI Journal 119

20. Hallett Carr E, Ruska revolucija: Od Lenjina do Staljina 1917.-1929 (Globus 1984)

21. Harris E, 'Paradoks, kontroverza i nacionalno samoodređenje' (2015) 52(1) Politička misao 191

22. Hroch M,' Oblikovanje modernih nacija i nacionalni pokret 19. stoljeća' (1979) 11(1) Časopis za suvremenu povijest 23

23. Hutchinson J and Smith AD, Ethnicity (OUP 1996)

24. Hutinec G (ed), Prvi svjetski rat i poslijeratna Europa (1914.-1936.) (Jutarnji list 2008) 
25. Ivašković I, 'Polemike o statusu Države i Kraljevine SHS' (2020) 36(3-4) Pravni vjesnik 269

26. Jackson B, 'The Political Thought of Scottish Nationalism' (2014) 85(1) The Political Quarterly 50

27. Jones DV, 'The League of Nations Experiment in International Protection' (1994) 8 Ethics \& International Affairs 77

28. Karabegović I, 'Kraljevina Srba, Hrvata i Slovenaca: Historijska realnost' (2009) 3 Historijska traganja 11

29. Kardum L, Suton stare Europe: Europska diplomacija i Prvi svjetski rat (Golden marketing - Tehnička knjiga 2009)

30. Kirschbaum SJ, 'Czechoslovakia: The Creation, Federalization and Dissolution of a Nation-state' (1993) 3(1) Regional Politics and Policy 69

31. Korunić P, 'Nacija i nacionalni identitet' (2005) 36(1 2) Revija za sociologiju 87

32. Korunić P, Rasprava o izgradnji moderne hrvatske nacije: nacija i nacionalni identitet (Grafički zavod Hrvatske 2006)

33. Kotljarchuk A, 'Ethnic Cleansings and Russification' in Mats-Olov O (ed), Encyclopedia of the Barents Region, vol 1 (Pax Forlag 2016) 189-91

34. Kovač M, 'Raspadanje Austro-Ugarske i rađanje Kraljevine SHS u svjetlu francuske politike (od listopada do prosinca 1918.)' (2003) 35(1) Časopis za suvremenu povijest 141

35. Kurtović Š, Opća povijest prava i države, vol 2 (treće izdanje, Pravni fakultet 1994)

36. Lakoff S, 'Nacionalizam i demokracija' (2000) 37(1) Politička misao 56

37. Lenjin VI, O pravu nacija na samoodređenje (Kultura 1949)

38. Lenin VI, Lenin Collected Works, vol 6 (Progress Publisher 1964)

39. Lenin VI, Lenin Collected Works, vol 19 (Progress Publisher 1964)

40. Lenin VI, Lenin Collected Works, vol 22 (Progress Publisher 1964)

41. Lenin VI, Lenin Collected Works, vol 24 (Progress Publisher 1964)

42. Lenin VI, Lenin Collected Works, vol 26 (Progress Publisher 1972)

43. Lulić M, 'Pravo na samoodređenje u suvremenom međunarodnom pravu' (Doktorska disertacija, Pravni fakultet Sveučilišta u Zagrebu 2005)

44. Macmillan M, Paris 1919: Six Months That Changed the World (Random House 2002)

45. Margalit A and Raz J, 'National Self-determination' (1990) 87(9) Journal of Philosophy 439

46. Matić D, 'Nacionalizam, nacija i nacionalna država: Imaju li budućnost?' (2005) 14(1-2) Socijalna ekologija 75

47. Maurič E, 'Europski novi identitet' (1994) 3(6) Društvena istraživanja 695

48. Mcewen N and Petersohn B, 'Between Autonomy and Interdependence: The Challenges of Shared Rule after the Scottish Referendum' (2015) 86(2) The Political Quarterly 192

49. Moore M, On National Self-Determination' (1997) 45(5) Political Studies 900

50. Mullin R, The Russian Social-Democratic Labour Party 1899-1904: Documents of the 'Economist' Opposition to Iskra and Early Menshevism (Brill 2015)

51. Neuberger B, 'National Self-determination: A Theoretical Discussion' (2001) 29(3) Nationalities Papers 391

52. Ninčić D, The Problem of Sovereignty in the Charter and in the Practice of the United Nations (Brill Nijhoff 1970) 
53. Núñez JE, 'About the Impossibility of Absolute State Sovereignty' (2014) 27(4) International Journal for the Semiotics of Law 645

54. Pavković J, Ruska dualistička monarhija (Društvo za socijalnu podršku 2012)

55. Posavec Z, 'Nacija i nacionalizam kao temeljni fenomen političkoga' (1996) 33(2-3) Politička misao 226

56. Ratković S, 'Rasa, pleme, narod, nacija...' (1931) 3(1) Hrvatski geografski glasnik 205

57. Regan K (ed), Kolonijalna carstva i imperijalizam (1871.-1914.) (Jutarnji list 2008)

58. Rudolf D, 'Lekcije Prvog svjetskog rata' (2014) 20 Adrias 105

59. Schrijver N, 'Self-determination of Peoples and Sovereignty over Natural Wealth and Resources' in Stephen Marks (ed), Realizing the Right to Development: Essays in Commemoration of 25 Years of the United Nations Declaration on the Right to Development (United Nations 2013) 95-102

60. Seton-Watson H, Nations and States: An Enquiry Into the Origins of Nations and the Politics of Nationalism (Routledge 2019)

61. Sharp A, The Versailles Settlement: Peacemaking in Paris 1919 (Macmillan 1991)

62. Simpson B, 'The United States and the Curious History of Self-Determination' (2012) 36(4) Diplomatic History 675

63. Smith AD, 'Nationalism and Classical Social Theory' (1983) 34(1) The British Journal of Sociology 19

64. Smith AD, 'The Ethnic Sources of Nationalism' (1993) 35(1) Survival 48

65. Stalin JV, Works, vol 2 (Foreign Languages Publishing House 1953)

66. Šišić F, 'Kralj Aleksandar I. Karađorđević (1888.-1934.)' (1934) 13(34) Narodna starina 117

67. Škrabalo I, Samoodređenje i odcjepljenje: pouke iz nastanka države Bangladeš (Školske novine 1997)

68. Throntveit T, 'The Fable of the Fourteen Points: Woodrow Wilson and National Self-Determination' (2011) 35(3) Diplomatic History 445

69. Vučinić N, 'Pravo naroda na samoopredeljenje' [2002] 3-4 Prava čoveka 11

70. Vukas B, Etničke manjine i međunarodni odnosi (Školska knjiga 1978)

71. Whelan A, 'Wilsonian Self-determination and the Versailles Settlement' (1994) 43(1) International \& Comparative Law Quarterly 99

\section{PROPISI I DOKUMENTI}

1. Constitution of the Russian Soviet Federated Socialist Republic (Adopted by the Fifth All-Russian Congress of Soviets, July 10 1918) <https://www.marxists.org/history/ussr/government/constitution/1918/index.htm> pristupljeno 26. ožujka 2021.

2. Declaration of Independence (July 4 1776) <https://avalon.law.yale.edu/18th_century/declare. asp> pristupljeno 27. ožujka 2021.

3. Declaration of the Rights of Man (National Assembly of France, August 26 1789) <https://avalon. law.yale.edu/18th_century/rightsof.asp> pristupljeno 27. ožujka 2021.

4. Declaration of the Rights of the People of Russia (english translation from The Nation, December 28 1919) <https://www.marxists.org/history/ussr/government/1917/ 11/02.htm> pristupljeno 26. ožujka 2021.

5. Povelja Ujedinjenih naroda (NN-MU 15/1993) 
6. United Nations General Assembly, Inclusion in the International Covenant or Covenants on Human Rights of an Article Relating to the Right of Peoples to Self- Determination (A/RES/545 (VI), 5 February 1952)

\section{MREŽNI IZVORI}

1. Lenin V, Report on Peace (Second All-Russia Congress of Soviets of Workers' and Soldiers' Deputies, October 26 (November 8)) <https://www.marxists.org/ archive/lenin/works/1917/oct/25-26/26b. htm> pristupljeno 26. ožujka 2021.

2. President Woodrow Wilson's Fourteen Points (January 81918) <https://avalon. law. yale.edu/20th_ century/wilson14.asp> pristupljeno 27. ožujka 2021. 


\section{HISTORICAL DEVELOPMENT OF THE RIGHT TO SELF- DETERMINATION BETWEEN THE TWO WARS - LENIN VS WILSON}

\section{Summary}

The end of the two great world wars and the disappearance of the current political regimes have resulted in the creation of new states in the international order. With the collapse of multinational states and awakening of national consciousness, the aspirations of peoples for their own national states started to appear. Requirements for self-determination resulted primarily from the decolonization process, but also as a reflection of political relations in the post-war Europe. At the end of the First World War, there were events and people contributing to the development of rights of the people to self-determination and helping the oppressed nations in achieving their aspirations to decide their own destiny within their own national states. On the one hand, there were the workers' self-determination and revolution in Russia as essential elements in the development of the right to self-determination in the political principle and Lenin's attitudes on self-determination. On the other hand, there were fourteen points and US President Woodrow Wilson with his views on the right to self-determination.

Keywords: $\quad$ International Law, Self-Determination of Nations, Right to Self-Determination, Russian Revolution, Fourteen points of Woodrow Wilson 